\title{
KNOWLEDGE SHARING IN BUSINESS NETWORKS FROM THE BUILDING INDUSTRY
}

\section{Alina Czapla ${ }^{1}$}

\begin{abstract}
:
Introduction: Both networking and knowledge management can give a company a competitive advantage. But the combination of these two approaches is particularly interesting. Knowledge sharing is crucial in the building industry, because it is changing all the time nowadays. The knowledge of new technologies and environmentally friendly building materials is especially important for companies from the construction industry. Also an average investor, who plans on building a house, has a very low level of knowledge about building materials and modern building technologies. So it is not surprising, that there are some business networks in building industry, which use knowledge sharing in their strategy.

Objectives: The objective of this study is to explore the knowledge sharing in business networks from the building industry. Our research question is: what forms of knowledge sharing take place in the construction industry and what is the scale of this phenomenon.

Methods: The case study method was used to analyze one of the largest and fastest growing Polish business networks of small and medium-sized enterprises (SMEs) - Grupa Polskie Składy Budowlane (PSB). The survey among the owners and managers was carried out, interviews, document studies and observations were used.

Results: Both the sharing of date and a large number of educational activities were observed in the studied business network. The vast majority of network members are engaged in these actions. Knowledge sharing in the building industry is implemented not only in relation to network partners and their employees but also in relation to customers.

Conclusions: A business network can use knowledge management to achieve its business goals. The educational aspects of this approach are especially interesting. The scale of this phenomenon in the building industry is much bigger than it might seem. The range of these educational actions can go beyond the formal boundaries of the network.
\end{abstract}

JEL Classification Numbers: L100, L140, DOI: 10.12955/cbup.v7.1339

Keywords: knowledge sharing, knowledge management, business network, case study, building industry.

\section{Introduction}

Globalization and growing competition resulted in the rapid development of business networks at the end of the last century. Thanks to the synergy effect even small companies, united in various types of network organizations, can effectively fight against external competition. These structures have been studied since the 1980s.

More or less, at the same time, attention was paid to knowledge management. There is no doubt, that knowledge became the driving force of the knowledge economy, and the knowledge economy became the engine of global economy growth (Bolisani \& Bratianu, 2018). Knowledge, like all other resources, has to be properly managed (Arsenijević et al., 2017). Currently knowledge is a very important issue in economy. It is a factor of competitiveness and economic growth (Runiewicz-Wardyn, 2008). Knowledge becomes a strategic factor for the development and growth of competitiveness. The knowledge-based economy, the new economy and the network economy in the knowledge society are new directions for the development of the modern world (Skrzypek, 2018).

Both networking and knowledge management can give a company a competitive advantage. So it can be interesting to connect these two approaches.

The construction industry is changing all the time nowadays. This applies to both building materials and construction technologies.

The selection of materials plays an important role in building construction (Florez \& Castro-Lacouture, 2013). Environmentally friendly building materials and constructions are intended to reduce energy and material flows during the entire building life cycle. Energy effective houses increase the efficiency of source utilization (energy, water and materials). They are designed to decrease negative effects on human health and the environment during their life cycle (Sedláková et al., 2012). Improving energy efficiency in buildings is a major priority worldwide (Diakakia et al., 2010).

The knowledge of new construction technologies is very important. Builders need to learn all the time to be up to date. They not only have to know modern building materials but also how to use them. We can observe the phenomenon of engaging producers and sellers of building materials in the training of builders.

\footnotetext{
${ }^{1}$ Faculty of Informatics and Communication, University of Economics in Katowice, alina.czapla@edu.uekat.pl
} 
The aim of this article is to explore the topic of knowledge sharing in business networks from the building industry. The author's intention was to research an example of such structure and show, how it works in practice. The scale of this phenomenon and forms of knowledge sharing were analyzed.

The case study method was used to analyze the Grupa Polskie Składy Budowlane (PSB) network - one of the largest and fastest growing Polish business networks of SMEs. The author used some qualitative research methods: survey, interviews, document studies and observations.

\section{Literature Review}

\section{Knowledge}

Knowledge has no clear definition so far. From the Greek philosophers up to present experts in knowledge management, people tried to define knowledge but the results are still not clear (Bolisani \& Bratianu, 2018). Nowadays the majority of the field's writers define knowledge as data, and this determines what they mean by knowledge management (KM) - part of IT. But KM can be understood as managing the relationship between knowing and acting in organizational contexts, part of which is managing the processes of knowing and learning towards organizational ends (Spender, 2015). This second approach is definitely more interesting.

In relation to knowledge, firms can identify the following basic processes: knowledge creation, knowledge acquisition, knowledge sharing and distribution, knowledge transformation, knowledge storing and retrieving, knowledge losing and knowledge using.

Knowledge creation is the final result of the learning process and conversely, learning occurs when we talk about the creation, sharing, and using of knowledge (Loermans, 2002), so knowledge and learning are related terms. A great deal of KM is about "knowledge sharing" rather than knowledge creation. It is also not clear whether it is organizations or people that learn (Spender, 2015). Knowledge sharing and distribution contribute to the restructuring of organizational knowledge and increase its average level (Bolisani \& Bratianu, 2018).

Knowledge is becoming one of the most important resources of the company (Arsenijević et al., 2017). Its assets are intangible in nature and include among others employees' skills and know-how, organizational culture, relationships with stakeholders and intellectual property (Moustaghfir, 2012). Knowledge assets provide firms with a competitive advantage (Loermans, 2002; Moustaghfir, 2012). Different learning mechanisms and effective knowledge management processes organize and integrate them into organizational capabilities. They explain above-average results and abnormal profitability (Moustaghfir \& Schiuma, 2013).

Knowledge Sharing

Knowledge sharing is defined sometimes as an exchange of knowledge between two individuals: one who communicates knowledge and one who assimilates it (Paulin \& Suneson, 2012). KS is often treated more broadly - as the exchange of knowledge between and among individuals, and within and among teams or organizational units inside an organization, however, the most interesting is the definition, which also takes into account the exchange of knowledge between organizations: knowledge sharing is the activities of transferring or disseminating knowledge from one person, group or organization to another. This definition broadly includes both tacit and explicit knowledge (Lee, 2001). This broad definition has been adopted in this study.

The similar term is knowledge transfer, which is defined, for example, as the focused, unidirectional communication of knowledge between individuals, groups, or organizations such that the recipient of knowledge has a cognitive understanding, has the ability to apply the knowledge or applies the knowledge. Both terms are often used when discussing the same concept (Paulin \& Suneson, 2012).

Knowledge sharing in an organization is an important aspect of knowledge management that contributes towards enhancing organizational learning to face competition (Abu-Shanab et al., 2014). It is one of the major predictors for outsourcing success. Organizational capability to learn or acquire the needed knowledge from other organizations is a key source of successful knowledge sharing (Lee, 2001).

Business Networks

In literature there are many studies of business networks. It is for several decades now that networks have been attracting much interest from strategic management researchers (Czakon, 2017). Most of them highlight the many advantages for the networks' members. Networks generate financial advantages through the sharing of costs and non-financial benefits, through the collective marketing and building 
of the image of products represented by these networks (Santos et al., 2018). Fuller-Love \& Thomas (2004) pay attention to developing their ability to operate on a more efficient and more profitable level and to create links between each other in order to exchange ideas and solve problems. Networks multiply the individual's capabilities, giving it an advantage in the ecosystem, in social or economic life (Czakon, 2012). Positive aspects include: access to new customers, access to new resources and knowledge transfer (Kawa \& Pierański, 2015). The key benefit of participation in a network is access to information flowing through it (Mitręga, 2010). Stoian et al. (2017) illustrate the role of inter-organizational networks in obtaining intermediate outcomes such as fostering innovative behavior and market knowledge. So networking can give a company a competitive advantage.

Knowledge Sharing in Business Networks

Knowledge transfer in business networks is determined by many factors, including: the structure of the network; the specificity of partners; and the absorptive capacity of the recipients of knowledge in the network and the ability and capacity of the broadcasters to disseminate knowledge (Sroka et al., 2014). Different organization types have different characteristics; knowledge sharing will produce different effects on the organization (Zheng, 2017). It is important to understand how knowledge flows and can be appropriated by network participants in order to generate innovation in processes, products and services, as well as improving organizational performance (Marchiori \& Franco, 2019).

We can distinguish two types of knowledge sharing: inside an organization and outside an organization. They are very different, both in terms of forms of sharing knowledge and goals to be achieved. However, in both cases, the involvement of the business network in sharing knowledge can bring many benefits.

\section{Research Methods}

The construction industry is one of the most important branches of the economy. The market of building materials and services has its specificity, however, the number of studies on this subject is small. In such a situation it is advisable to carry out exploratory research.

Both the problem and the method of solving it can be scientific or practical, however, it should be realized that management sciences arise from business activities and are inseparably connected with it. It is therefore desirable that the solution to the scientific problem in management is associated with practical solutions (Wójcik, 2013). It is one of the reasons why the case study method is suitable for studying management problems.

The case study method was used to analyze one of the largest and fastest growing Polish business networks of SMEs - Grupa Polskie Składy Budowlane. The strength of the case study is its ability to cover both a contemporary phenomenon and its context (Yin, 1981). The chosen method is suitable for this problem, because the study is an exploration of the topic. For this reason the qualitative method is better. Case studies are useful for generating hypotheses at the beginning of the research process (Starman, 2013). A case study enables a very accurate description and analysis of the studied phenomenon, which are often more comprehensive and more accurate than those obtained in quantitative studies (Grzegorczyk, 2015).

The research shows, how knowledge management is realized by the leader of this Group, by members of this Group and by this network as a whole structure. Survey research, interviews, document studies and observations were used. The survey was carried out during the conference of PSB network members in November 2018. It was a meeting of owners and managers of trading companies operating under this structure. The Group has about 400 members, about half of them participated in the conference. Most companies were represented by a number of people. So questionnaires not only were filled in by competent persons but additionally in most cases one paper was completed by few managers of the same company. As a result 50 questionnaires were correctly completed. The sample is not representative, nevertheless results of this survey have a great value.

Following the questionnaire, some interviews with business owners were requested to find out more about knowledge management in their companies. This was done to supplement the numerical data. Opinions, comments and impressions complement the knowledge from the survey.

Document studies and observations are the important part of this research. Summary reports, publications, post-conference materials were studied. Additionally, reports from educational actions organized by PSB members were observed. 


\section{Choice of the Case}

Grupa Polskie Składy Budowlane is the network of building material stores. The members of this Group run three types of stores: wholesales, DIY markets - Mrówka (Ant) and specialist shopping centers for constructors - Profi.

This business network was chosen for this research because of some important reasons. Above all, this business network is particularly involved in knowledge sharing. Additionally, the size of this network is large, so it is easier to observe various phenomena; some data is easily available; the simple structure of this network (one strong leader and many shareholders - figure 1) makes it easier to formulate conclusions; the simple structure and huge size give a chance to generalize.

\begin{tabular}{|l|l|l|l|l|l|l|}
\hline \multicolumn{1}{l|}{ Figure 1: The structure of PSB network } \\
\hline
\end{tabular}

Furthermore, the author has professional experience in this industry.

\section{Research Results and Discussion}

Knowledge Transfer Organized by the Leader of PSB

PSB Central Office is interested in sharing knowledge with partners. The structure of this network is vertical and development of organization members is beneficial both for the leader and for the whole network. Therefore, many efforts are made to provide information to all partners. A special internet platform was created. It contains a large number of constantly updated industry offers and trade conditions. Additionally, every day members receive lots of new information via e-mail. The scope of this knowledge is very wide. It is connected not only with the building industry, but also with legal changes or running a business. Shareholders are informed about new threats and opportunities.

Conferences for the owners and managers of PSB's points of sale are organized every year. They are informed about trends in the building industry. Network activity is analysed in comparison to the competition.

The other kind of leader's activity is equally important. The PSB Central Office throughout its own specialists as well as their suppliers realizes various training series for network employees, for instance: technical training to increase the knowledge about suppliers' products and technologies among the sales employees from retail and wholesale branch offices; training on service procedures and standards in Mrówka outlets; soft skills training for managers and sellers (sale, customer service and management); "Mini-MBA of Grupa PSB" - there was the fourth edition of eight two-day sessions for managing staff and owners about management, team creation, negotiations, finance and logistics in 2017.

The leader of the PSB prepared an on-line training calendar and e-learning platform to amend and coordinate all training types for the whole network. An important service offered by the PSB Central Office to its partners is the consulting of auditors - specialists who help to manage trading enterprises.

But the leader of the PSB educates not only partners and their employees but also customers. The educative campaign "Modern House" is organized for them. The purpose of this campaign is to promote modern building. It enables investors to exploit their new houses more cheaply and live in peace with nature. They are also informed about the newest solutions and products in the building industry. Additionally, a unique movie series was prepared. It consists of 25 episodes about the process of house construction. The movies are a set of advice, that will be useful for everyone who wants to start building a house. They are available on the PSB website (Grupa PSB, 2017).

Several specialized magazines are published by the PSB Central Office. For instance, the magazine "Głos PSB" ("The Voice of PSB") is printed bi-monthly. About 26000 copies are distributed to constructors and Builders' schools. The magazine is also available online.

Knowledge Transfer in SMEs - Members of PSB Business Network 
Knowledge sharing can also be observed among partners. They send data about their enterprises to the Central Office and share their experiences. However the greatest commitment can be observed in training.

Fifty SMEs from all over Poland - members of the PSB business network took part in the survey. In terms of the number of employees: 17 of them are medium-sized (50-249 employees), 30 of them are small (10-49 employees) and 3 of them are micro (0-9 employees). In terms of the type of business: 25 of them run a construction warehouses, 36 of them run retail DIY stores - Mrówka, 10 of them run specialist shops for contractors - Profi (some of them several types).

The companies' educational activity was analyzed. Members of PSB organize a huge number of various training sessions both for employees and customers. The number of enterprises involved in particular educational activities is shown in Figure 2.

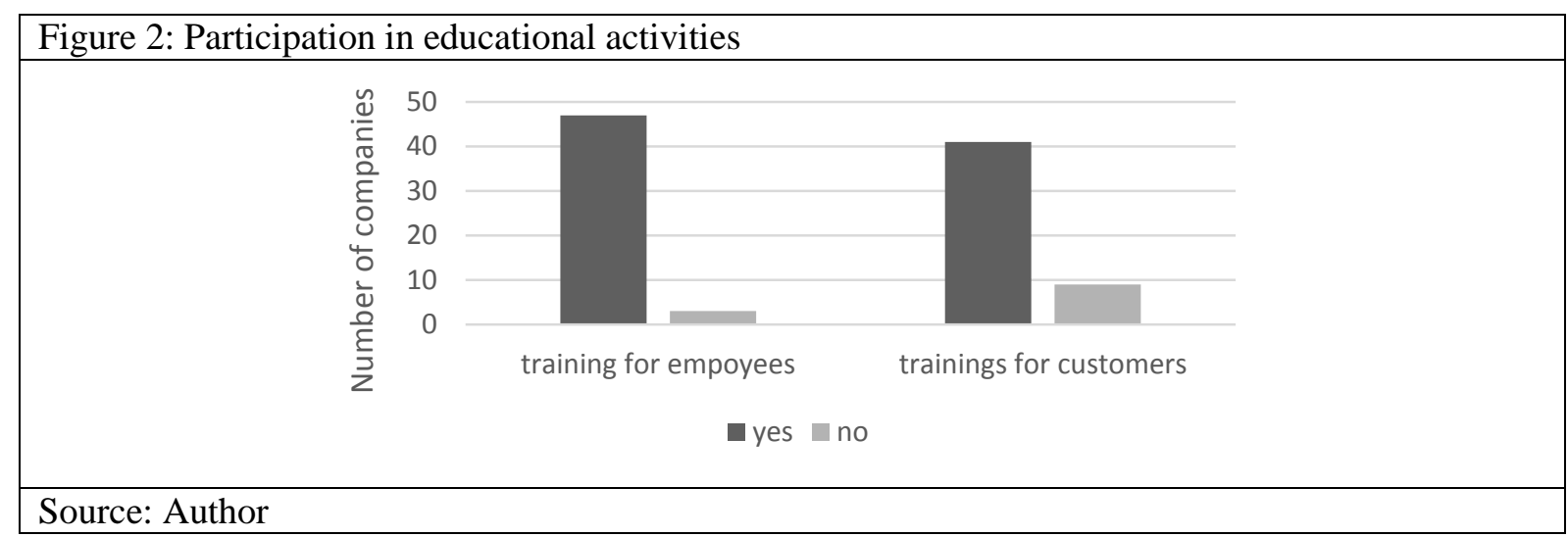

The results are astonishing. Almost all enterprises organize training sessions for employees and $82 \%$ of them train customers. Staff training is rather natural, but the scope of this phenomenon is surprising. The scale of customer training is amazing and is certainly a part of the strategy.

To analyse this phenomenon, the percentage of companies participating in educational activities in particular types of business was calculated (Figure 3).

\begin{tabular}{|l|l|l|l|}
\hline $\begin{array}{l}\text { Figure 3. Percentage of companies participating in educational activities in particular types of } \\
\text { business }\end{array}$ \\
\hline
\end{tabular}

All Profi shops and almost all wholesales declare organizing training for customers. The number of such initiatives during the last year was around 300 and the number of participants around 5000. Training sessions for employees were prepared by all wholesales and Profi shops and in more than $91 \%$ of retail markets Mrówka. The number of these actions was about 270 and the number of participants was greater than 1300 (Czapla, 2019).

Knowledge Transfer in PSB as a Whole Structure

The PSB network organizes a large number of educational actions. In most of them both the leader of the group and members are engaged. For instance the "PSB School of Good Building" is the biggest training program for constructors - the customers of PSB's points of sale. The "PSB Academy" is the 
project, which has been realized for years by Grupa PSB as different training for various participants. In total, over 8000 listeners took part in trainings within the "PSB Academy" in 2017. It was, undoubtedly, the biggest educational project in the construction industry in Poland. The expenditures for these training sessions incurred by suppliers are estimated to be over 600000 PLN and by PSB Partners - 450000 PLN (Grupa PSB, 2017).

Knowledge management is not formally entered in the network strategy, but it can be easily observed, that this part of the organization's activity plays an important role in business running. Special importance of training is constantly underlined in PSB publications, in interviews, and during conferences. And, what is more important, sharing of knowledge is realizing all the time.

The range of these educational actions goes beyond the formal boundaries of the network. The PSB network educates not only Partners and their employees, but also customers with the inclusion of individual clients. This approach is rather unconventional and can be an example worth imitating. Future research can show this.

\section{Conclusions}

There is no doubt, that both networking and knowledge management can give a company a competitive advantage. The literature review shows this clearly. But the combination of these two approaches is particularly interesting.

The research points out that a business network can use knowledge to achieve its business goals. In the analyzed building industry the scale of this phenomenon is much bigger than it might seem. However, sharing data in a vertical-structured organization is quite natural, but the amount of various educational actions is very surprising. It is all the more interesting that a large number of these activities is dedicated to customers. Both construction companies and individual clients are educated. It is also surprising that the vast majority of network members is engaged in this process.

This study has limitations. This paper analyzes only one business network and only qualitative research was conducted. It is just the exploration of the topic and the first step to future studies. Nevertheless, Grupa Polskie Składy Budowlane is a very interesting example of a knowledge-based business network. The research shows the scale of involvement in the knowledge sharing process, but the results of this process were not measured.

Future research directions should include more case studies to explore more precisely this topic in various business networks. Not only the scale of this phenomenon should be examined, but also the results should be measured. Based on the results of qualitative research, quantitative research is recommended.

\section{References}

Abu-Shanab, E., Haddad, M., \& Knight, M. B. (2014). Knowledge Sharing Practices and the Learning Organization: A Study. The IUP Journal of Knowledge Management, 12(2), 38-50.

Arsenijević, O., Trivan, D., Podbregar, I., \& Šprajc, P. (2017). Strategic aspect of knowledge management. Organizacija, 50(2), 163-177. DOI: https://doi.org/10.1515/orga-2017-0011.

Bolisani, E., \& Bratianu, C. (2018). Emergent knowledge strategies. Strategic thinking in knowledge management. Springer. DOI: https://doi.org/10.1007/978-3-319-60657-6.

Czakon, W. (2012). Sieci w zarządzaniu strategicznym [Networks in strategic management]. Warszawa: Wolters Kluwer.

Czakon, W. (2017). Strategies of networked organizations. The Research Journal of the Chorzow Faculty of the Poznan School of Banking, 19, 71-81.

Czapla, A. (2019). Corporate social responsibility in small and medium-sized enterprises. Humanitas University's Research Papers Management, 20(1), 117-124. DOI: https://doi.org/10.5604/01.3001.0013.2425.

Diakakia, C., Grigoroudisb, E., Kabelisb, N., Kolokotsac, D., Kalaitzakisd, K., \& Stavrakakis, G. (2010). A multi-objective decision model for the improvement of energy efficiency in buildings. Energy, 35(12), 5483-5496. DOI: https://doi.org/10.1016/j.energy.2010.05.012.

Florez, L., \& Castro-Lacouture, D. (2013). Optimization model for sustainable materials selection using objective and subjective factors. Materials \& Design, 46, 310-321. DOI: https://doi.org/10.1016/j.matdes.2012.10.013.

Fuller-Love, N., \& Thomas, E. (2004). Networks in small manufacturing firms. Journal of Small Business and Enterprise Development, 11( 2), 244-253. DOI: https://doi.org/10.1108/14626000410537182.

Grupa PSB. Summary report 2017. https://www.grupapsb.com.pl/files/BlockFileImage/p2nrsun0gatn6n/ psb_raport2017_ 180518_internet.pdf. 
Grzegorczyk, W. (ed.) (2015). Studium przypadku jako metoda badawcza i dydaktyczna w naukach o zarządzaniu [Case study as a research and didactic method in management sciences]. Łódź: Wydawnictwo Uniwersytetu Łódzkiego.

Kawa, A., \& Pierański, B. (2015). Współpraca sieciowa przedsiębiorstw w Polsce - wyniki badań [Enterprise networking in Poland - research results]. Zeszyty Naukowe Wyższej Szkoły Bankowej w Poznaniu, 64(7), 23-34. DOI: https://doi.org/10.13140/RG.2.1.4088.0089.

Lee, J. N. (2001). The impact of knowledge sharing, organizational capability and partnership quality on IS outsourcing success. Information \& Management, 38, 323-335. DOI: https://doi.org/10.1016/S0378-7206(00)00074-4.

Loermans, J. (2002). Synergizing the learning organization and knowledge management. Journal of Knowledge Management, 6(3), 285-294. DOI: https://doi.org/10.1108/13673270210434386.

Marchiori, D., \& Franco, M. (2019). Knowledge transfer in the context of inter-organizational networks: Foundations and intellectual structures. Journal of Innovation \& Knowledge. https://www.sciencedirect.com/science/article/pii/ S2444569X19300216?via\%3Dihub. DOI: https://doi.org/10.1016/j.jik.2019.02.001.

Mitręga, M. (2010). Zdolność sieciowa jako czynnik przewagi konkurencyjnej na rynku przedsiębiorstw [Networking ability as a competitive advantage on the business market]. Katowice: Wydawnictwo Akademii Ekonomicznej w Katowicach.

Moustaghfir, K. (2012). Explicating knowledge-based competitive advantage. International Journal of Synergy and Research, 1(1), 23-38.

Moustaghfir, K., \& Schiuma, G. (2013). Knowledge, learning, and innovation: research and perspectives. Journal of Knowledge Management, 17(4), 495-510. DOI: https://doi.org/10.1108/JKM-04-2013-0141.

Paulin, D., \& Suneson, K. (2012). Knowledge Transfer, Knowledge Sharing and Knowledge Barriers - Three Blurry Terms in KM. The Electronic Journal of Knowledge Management, 10(1), 81-91.

Runiewicz-Wardyn, M. (2008). Knowledge-Based Economy as Factor of Competitiveness and Economic Growth. Warszawa: Wydawnictwa Akademickie i Profesjonalne.

Santos, G., Marques, C. S., \& Ratten, V. (2018). Entrepreneurial women's networks: the case of D'Uva - Portugal wine girls. International Journal of Entrepreneurial Behavior \& Research. DOI: https://doi.org/10.1108/ijebr-10-2017-0418.

Sedláková, A., Vojtuš, J., \& Krídlová Burdová, E. (2012). Design of consumer model and environmental assessment of used building materials. Proceedings of the International Multidisciplinary Scientific GeoConference SGEM, 5, 235-242. DOI: https://doi.org/10.5593/sgem2012/s20.v5033.

Skrzypek, E. (2018). Knowledge-Based Economy as a Contemporary Challenge. Myśl Ekonomiczna i Polityczna, 2(61), $17-$ 47.

Spender, J. C. (2015). Knowledge management: Origins, history, and development. In E. Bolisani \& M. Handzic (Eds.), Advances in knowledge management: Celebrating twenty years of research and practice (pp. 3-23). Heidelberg: Springer. DOI: https://doi.org/10.1007/978-3-319-09501-1_1.

Sroka, W., Cygler, J., \& Gajdzik, B. (2014). Knowledge Transfer in Networks - the Case of Steel Enteprises in Poland. Metalurgija, 53(1), 101-104.

Starman, A. B. (2013). The case study as a type of qualitative research. Journal of Contemporary Educational Studies, 1, 2843.

Stoian, M. C., Rialp, J., \& Dimitratos, P. (2017). SME networks and international performance: unveiling the significance of foreign market entry mode. Journal of Small Business Management, 55(1), 128-148. DOI: https://doi.org/10.1111/jsbm.12241.

Wójcik, P. (2013). Znaczenie studium przypadku jako metody badawczej w naukach o zarządzaniu [The importance of a case study as a research method in management sciences]. E-mentor, 1(48). http://www.e-mentor.edu.pl/artykul/index/ numer/48/id/983.

Yin, R. K. (1981). The Case study as a Serious Research Strategy. Knowledge: Creation. Diffusion, Utilization, 3, 97-114. DOI: https://doi.org/10.1177/107554708100300106.

Zheng, T. (2017). A Literature Review on Knowledge Sharing. Open Journal of Social Sciences, 5, 51-58. DOI: https://doi.org/10.4236/jss.2017.53006. 